\title{
二本と三本指の把持動作による長さ知覚の差異*
}

\author{
王 海 波*1, 点 景 龍*2, 北澤 雅 之*3
}

\section{Difference of Human Tactile Length Perception Between Two and Three Fingers Grasping}

\author{
Haibo WANG, Jinglong WU ${ }^{* 4}$ and Masayuki KITAZAWA \\ ${ }^{* 4}$ Graduate School of Natural Science and Technology, Okayama University, \\ 3-1-1 Tsushima-naka, Okayama-shi, Okayama, 700-8530 Japan
}

\begin{abstract}
In order to improve the operation precision of the remote manipulation systems, it is necessary to clarify the human characteristic of length perception by using fingers. In previous studies, the length perception has not been investigated using multi-fingers grasping. Therefore, we developed a tactile length measuring system in this study. By using this system, some experiments were made to clarify the human length perception for fingers (thumb, index finger, middle finger). These results suggest that human tactile length perception in case of three fingers using is better than that of two fingers (thumb and index finger) condition.
\end{abstract}

Key Words : Biomechanics, Human Engineering, Man-Machine-Communication Tactile Length Perception, Multi-Fingers Grasping

\section{1. 緒 言}

遠隔操縦を行う場合, 操作者は入力に対する遠隔地 の出力をセンサーや視覚で観察し，修正量をフィード バックする. 操作者の操作技術を遠隔地で活かすため には，人の知覚特性を考慮したマンマシン・インタフ エイスが必要となってくる，これの基礎となる人の知 覚に関する研究，なかでも，長さ知覚に関する研究は 盛んに行われてきた. D.Burke らの研究によると，指 の把持動作による長さ知覚は関節，筋肉，皮膚の感覚 から情報を得ているといわれている(1).そのため，大 きな対象物を把持するときは指先間を大きく開き，小 さな対象物を把持するときは小さくする. このとき, 手の虫様筋, 屈筋と伸縮筋等も活動しており ${ }^{(2)}$, 触覚と 運動感覚が同時に活動している.

呈示した長さと知覚した長さの比較についても，多くの 研究がなされてきた H.F.Gaydos は, 長さ 25〜100 $\mathrm{mm}$ のア ルミニウム円柱体を手で触れさせ，その長さを親指と人差 し指で再現させる䒠験を行った ${ }^{(3)}$. A.G.Dietze は, 厚さ10, 30,50 $\mathrm{mm}$ の円柱体を標淮束激とし，長さ知覚閾值実験を行 った(4). 呂らは，対象物の形狱知覚機能を解明するため, 親 指と他の一本の指をランダムに選択し，その二本指を用い て長さ知覚特性実験を行った (す)。しかし, 訌験片を被験者の

* 原稿受付 2009 年 7 月 31 日.

*1 岡山大学大学院自然科学研究科 ( $-300-8530$ 岡山市津島中 3-1-1).

*2 正員, 岡山大学大学院自然科学研究科.

*3 正員, 和歌山工業高等専門学校 ( $644-0023$ 御坊市名田町 野島 77).

E-mail : wu@mech.okayama-u.ac.jp
手に持たせて測定を行ったため，得られた長さ知覚特性に は試験片の重量感覚の要素も含まれている可能性がある。

また，K.OJohnson and S.S.Hsiaoは，人が物のサイズ, 形状，材質などの表面性質を知賞する際，知覚情報は皮膚 受容器から神経システムに伝達されることを報告してい る(の. 皮膚感覚は，人間の皮膚下に存在する四種類の皮膚 受容器が皮膚の変形と皮膚に与えられた圧力を検出する ことによって生じる感覚である゙．長さを知覚するとき， 接触した表面の材質, 硬さ, 接触面積などの要素も長さ知 覚に影響することは知られている(8)。これら諸要素の中で, S.Gepshtein\&M.S.Banks の研究より, 対象物の呈示方向が 長さ知覚に影響しないことが明らかになっている(9)。さら に，LJ.Bernyman らは親指と人差し指を用いた $50 \sim 62 \mathrm{~mm}$ の範囲の実験において，指と接触した大きさと把持力が人 間の長さ知覚に影響しないことを明らかたしている゙

以上のように，指の長さ知覚についての研究は一本指(ほ とんぞか親指と人差し指）に関するものであり，それら以 外を用いた実験結果には，長さ以外の知覚特性が含まれて いる可能性がある. また人の動きを入力とするヒューマノ イド型ロボット等では，計測された動きをそのまま伝える ため，指の種類や本数による感賞の差を伝達することがで きない: 指の種類や本数による知覚特性か淜らかれななれ゙， 人の感覚と一致したマンマシン・インタフェイスの開発が 可能となる. そこで, 本研究では，指に長さ刺激のみを呈 示する実験装置を製作し，二本指と三本指の把持動作によ る長さ知覚の差異について被験者実験を行う. その結果よ り，二本指と三本指の長さ知覚の差異を検討する. このと 
き，指先は必ず刘象物と接触することから，皮膚感覚も長 さ知覚に影響を与えると考えられる，そのため，実験装置 の指先と接触する部分は，表面粗さや形状を考慮して，ア クリル円板とした. また，文献(10)とは使用する指の本数な どが異なるため，把持力についても計測した

\section{2. 実験方法}

2-1 被験者 被験者は健常な 21 歳 30 歳の男性 10 名 (利き手は右手)。実験内容について十分な説明を行っ た後，被験者実験（右手を使用）を行った，10 名被験者 の中指の長さは73〜82mm まで、平均 79.3mm であり、人 差し指の長さは $67 \sim 76 \mathrm{~mm}$ まで平均 $72.7 \mathrm{~mm}$ である.

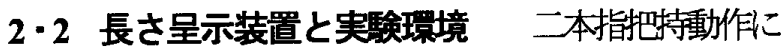
よる長さ呈示装置を図 1 に示す.二本指把持動作とは親指 と人差し指または親指と中指を用いてものを把持するこ とをいい，二本指て把持する部分の抗大図を図 1(a)に示寸。
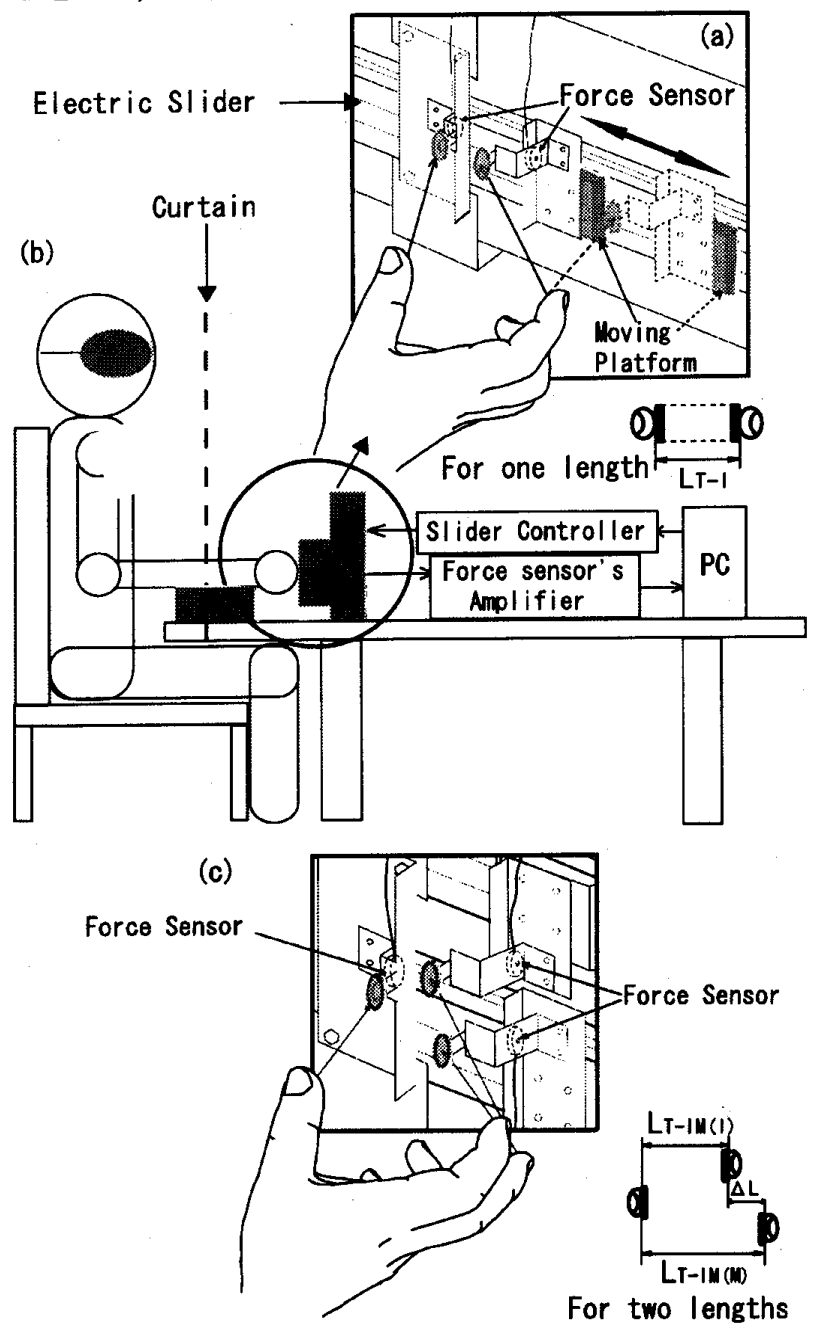

Fig.1 Length perception device for two and three fingers experiments

各指が把持する部分には，接触したときの感覚を統 一するために, アクリル円板を取り付けた.これらの
アクリル円板は, カセンサー (Force Sensor 東京計器研 究所CLS-NA 定格出力 $1 \mathrm{mV} / \mathrm{V} \pm 20 \%)$ が装着された アルミ支持材にそれぞれ取り付けられており，各指が 把持する力はこれらのセンサーによって計測し，コン ピュータ（以下，PC と呼ぶ）に記録できるようになっ ている. 親指が把持する側のアルミ支持材は固定され ており，動くことはない，一方，人差し指または中指 が把持する側のアルミ支持材は，移動台（Moving Platform）に取り付けられており，図中の矢印方向に任 意の距離だけ移動することができる. 図中の点線は, 移動後のアルミ支持材を表したものである.この移動 台の移動量は PC からの指令により制御することがで きる. これにより，任意の長さを被験者の二本の指に 呈示することが可能となっている.

一方，三本指把持動作とは，親指,人差し指および 中指の三本指を用いてものを把持する動作をいう. 三 本指の把持動作による長さ知覚実験を行う場合は, 図 1(c)に示す把持部分を三本の指で把持する. 二本指の 把持部分と同じように，アクリル円板が装着されてお り，把持力はアルミ支持材に取り付けられている力セ ンサーによって計測される. 人差し指と中指が把持す る側のアルミ支持材はそれぞれ異なる移動台に取り付 けられているため，これらを独立して動かすことで三 本の指先間に任意の二種類の長さ刺激を呈示すること ができるようになっている.

実験は十分静かな実験室で行い，被験者はアイマスク を着用した，そして，図 1 に示すように被験者と実験装 置の間にカーテンを設置し，被験者が呈示装置を見るこ とができないように工夫した. また, 図1に示すように, 被験者には椅子に腰掛けた状態で背筋を伸ばすように指 示し, 肘関節角度が約 90 度になるように椅子の高さを調 整した。被験者の手首をマジックバンドで固定し，腕が 動かない 状態で親指と人差し指が荝刺激呈示部と同じ高さ になるように調整した。

\section{$2 \cdot 3$ 実験の種類 長さ認知時に使用する指の本数の} 影響を調へるため，まず，二本指の間に長さを呈示する実 験 1 と三本指を用いる実験 2 を用意した これらの実験で は一種類の長さ刺激を呈示する. その呈示方法を図 2 に示 す. 実験 1 は親指一人差し指間（し $\mathrm{L}_{\mathrm{T}}$ と定義する）と親旨一 中詣間 ( $\mathrm{L}_{\mathrm{T} M}$ と定義する) に長さ刺激を呈示する. 実験 2 は図 2(a) (T-IM)に示すように，親旨一人差し指間と親指一 中詣間に同じ長さ刺敔（L TAM と定義する）を呈示する. 寒 験刺激は 10〜100 $\mathrm{mm}$ まで5mm 刻みの長さをランダムに呈 示し，各長さに対して5 回測定する. 
次に，三本指て物を把持方る際の知覚特性をさらに精査 するため，図 2(b)に示すように二種類の長さ刺激を同時に 呈示寸る実験も用意した (実験 3 )。親指一人差し指間に呈 示した長さを $\mathrm{L}_{\mathrm{T} \mathrm{MM}(\mathrm{M})}$ ，親指一中指間に呈示した長さを $\mathrm{L}_{\mathrm{TIMM})}$ と定義する. そして，二つの長さの差を $\Delta \mathrm{L}$ と定義する. 実験 3 では一つ刺激として 10〜100mm まで $10 \mathrm{~mm}$ 刻み の長さを呈示し，それに対して2,4,6,8,10,12mm の差を持つ 長さをもう一の刺激としてランダムに呈示する.

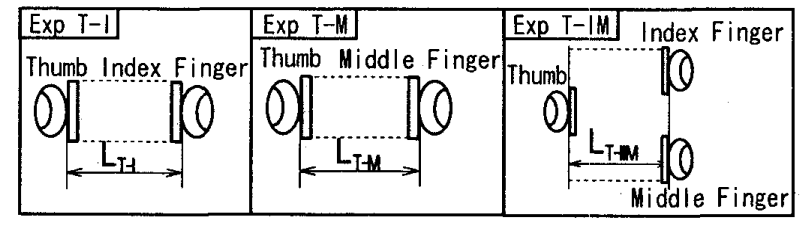

(a) One length perception experiment

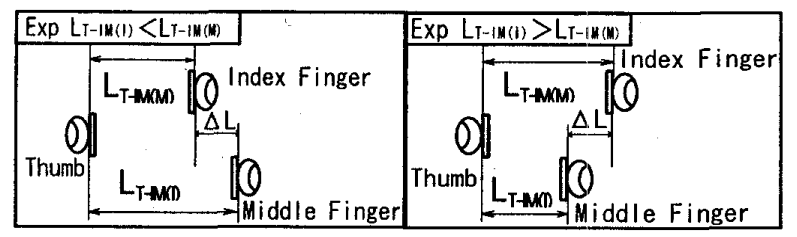

(b) Two lengths perception experiment

Fig.2 One and two lengths perception experiment

$2 \cdot 4$ 実験手順 実験 1 については以下の手順で 実験を行った. まず, 実験刺激を呈示する前, 被験者 は自然状態で親指と人差し指（または中指）を開き， 他の指も自然状態とする，次に，実験者が実験刺激の 長さを設定し，被験者に実験開始を告げる．そして， 被験者は親指と人差し指（または中指）で奏験刺激を 把持して, その長さを知覚する. 知覚後, 親指と人差 し指（または中指）を実験刺激から離し，知覚された 長さを $\mathrm{mm}$ 単位で口頭で答える。このとき，実験者は 被験者が回答した長さを記録する，実験内容を理解す るとともに装置に慣れるため, 被験者は実験開始前に 数回の練習試行を行った.

実験 2 および 3 も実験を行う順序は実験 1 とほとんど同 じであるため，ここでは，異なる部分のみ説明する．被験 者は自然状態て親指，人差し指と中指を開き，他の指も自 然状態とする. 実験刺激の長さ $\mathrm{L}_{\mathrm{T}-\mathrm{M}}$ （実験 3 では $\mathrm{L}_{\mathrm{T}-\mathrm{MM}}$ と L T-MM） を設定後，実験を開始する. 被験者は親指，人差し 指と中指を用いて呈示刺激を把持し，その長さを知覚する. 知覚後, 各指を䒠駼刺激力ら離し，知覚された長さ $\mathrm{L}_{\mathrm{TIM}}$ (実 験3 では $\mathrm{L}_{T A M()}$ と $\mathrm{L}_{T A M M}$ の二つ) を $\mathrm{mm}$ 単位て答える.

\section{3. 奏輪秸果}

\section{$3 \cdot 1$ 一種類の長さ知覚結果（実験 1 と 2)}

親指と
人差し指，親指と中指を用いた実験結果，また，三本 指を用いた実験 2 の結果を図 3 に示す。いずれも横軸 は実際に呈示した長さを示し，綐軸は被験者の知覚し た長さを示す. 図中の 45 度の点線は呈示した実際長さ が被験者を知覚した長さと一致する場合を意味してい る．図中のプロット点は被験者 10 名の平均值である.

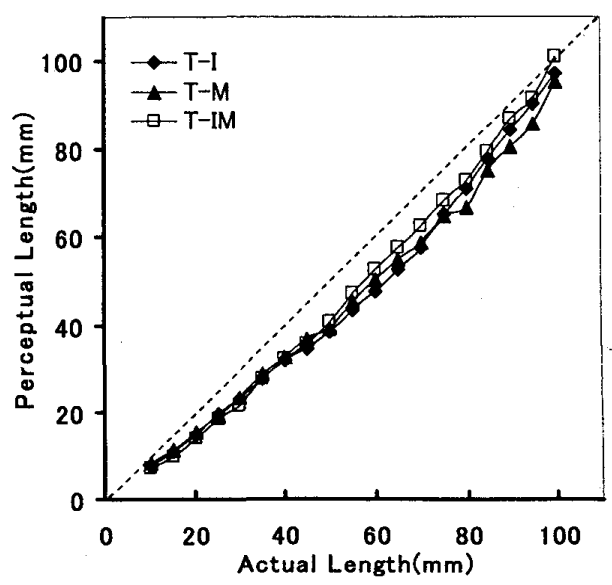

Fig.3 Average of one length perception with two and three fingers

図 3 において，二本指の結果は全体的に呈示した実 際長さが長くなると，被験者が知覚した長さも長くな る傾向が見られる. また，知覚された長さはすべて 45 度直線より下方に位置することから，知覚された長さ は実際長さより短く知覚されている. 三本指の場合も 二本指の結果と同様に呈示長さが長くなると, 被験者 が知覚した長さも長くなる傾向が見られる．また，呈 示長さ $100 \mathrm{~mm}$ の条件を除き,知覚された長さは二本指 の結果と同様に呈示された長さより短く知覚される結 果が得られた。

呈示した長さと知覚誤差の関係（被験者 10 名の平 均值）を図 4 に示す．知覚誤差とは被験者が知覚した 長さと呈示長さの差を意味し,式(1)のように定義する。

$$
P E=P L-A L
$$

式中の PE (Perceptual Error) は知覚誤差, PL (Perceptual Length）は知覚した長さ，AL（Actual Length）は実際に 呈示した長さを示す．図中の菱形印(•)と三角形印(ム) は，それぞれ実験 1 の親指一人差し指間(T-I) と親指一中 指間(T-M)の知覚誤差を示し，正方形印 (口)は実験 2 の 親指一人差し指・中指間(T-IM)の三本指を用いたときの 知覚誤差を示している.この図より，実験 2 の $100 \mathrm{~mm}$ 刺激の結果を除き, 各実験の知覚誤差は 0 以下であり, 呈示長さを過小評価している. 


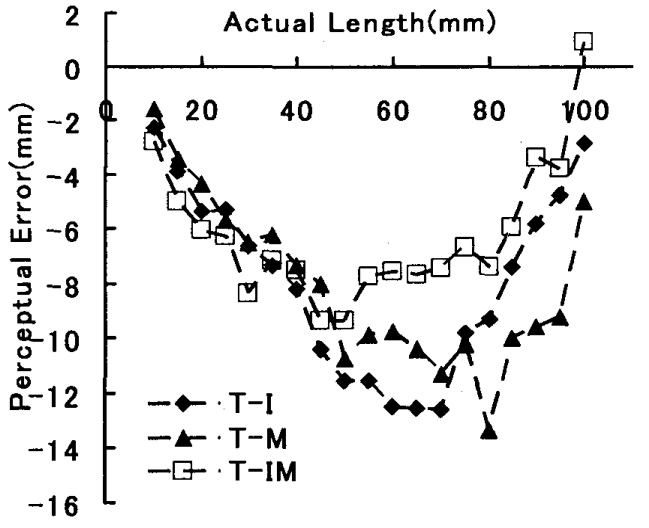

Fig.4 Experimental results of two and three fingers' grasping for one length perception experiment

$3 \cdot 2$ 把持力の計測結果 図 5 に親指と人差し指に よる長さ知覚実験(T-I) と親指,人差し指,中指による長さ知 覚実験(T-IM)の親指の平均把持力を示す. 横軸は呈示長さ であり，縦軸は，長さ刺激が呈示されたときに，被験者が それを把持している力である. 図より，両者の平均把持力 がほほ同じ傾向を示していることが分かる.

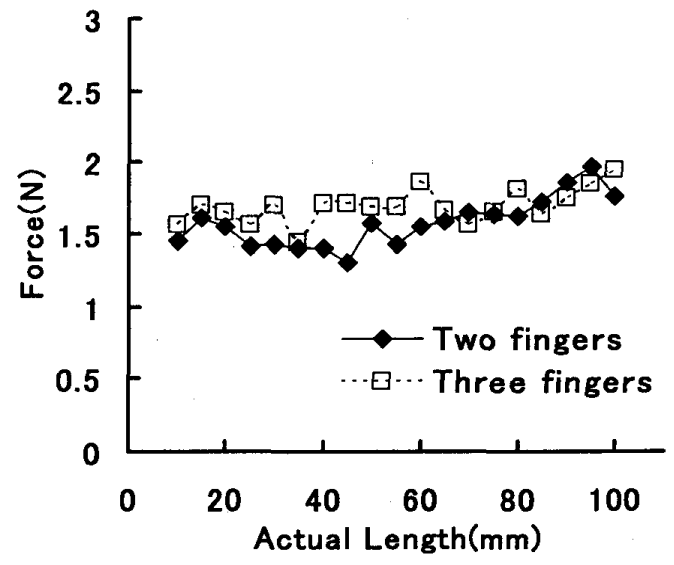

Fig.5 Finger force of two and three fingers' grasping for one length perception experiment

\section{3·3 二種類の長さ知覚結果 (実験 3) 三本指に} よる二種類の長さ知覚実験の結果を図 6,7 に示寸. 図 6 は呈示した二種類の長さが $\mathrm{L}_{\mathrm{T}-\mathrm{IM}(\mathrm{I})}<\mathrm{L}_{\mathrm{T}-\mathrm{MM} M}$ の場合であ る. 一方, 図 7 は $\mathrm{L}_{\mathrm{T}-\mathrm{M}(\mathrm{I})}>\mathrm{L}_{\mathrm{T}-\mathrm{M}(\mathrm{M})}$ の場合である.これら において，横軸は呈示長さ（図中の点線で囲んだ指間 に呈示した長さ），縦軸は知覚した長さを表す。この とき，呈示した二種類の長さの差を $\Delta \mathrm{L}$ とし，式(2)

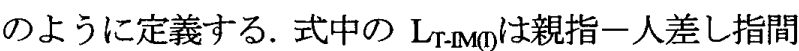
に呈示した長さ， $\mathrm{L}_{\mathrm{T}-\mathrm{M} M(\mathrm{M})}$ は親指一中指間に呈示した長 さを表す。

$$
\Delta L=L_{T-I M(I)}-L_{T-I M(M)}
$$

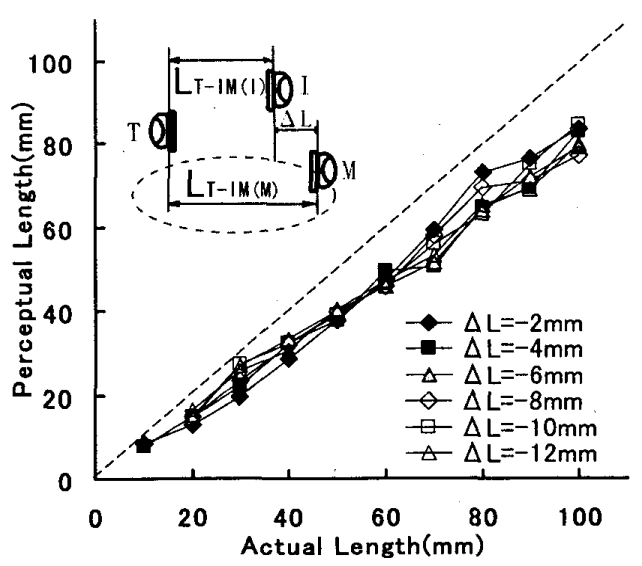

Fig.6 Results of two lengths perception when $\mathrm{L}_{\mathrm{T}-\mathrm{IM}(\mathrm{I})}<\mathrm{L}_{\mathrm{T}-\mathrm{IM}(\mathrm{M})}$

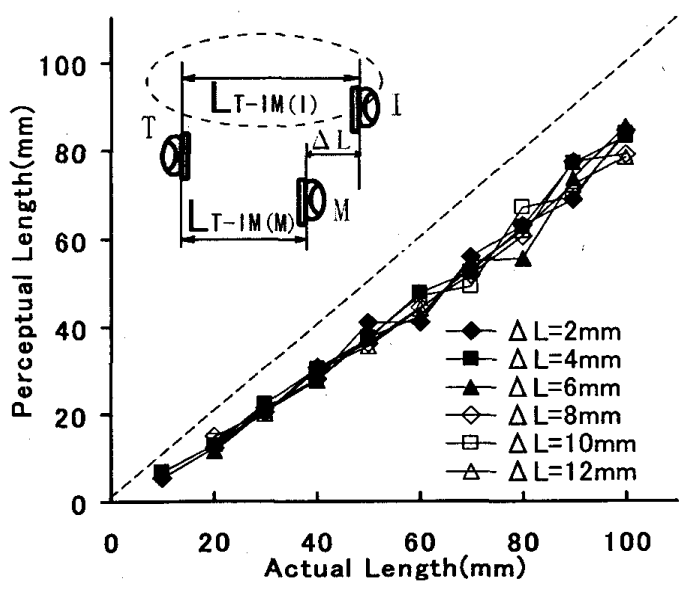

Fig.7 Results of two lengths perception When $\mathrm{L}_{\mathrm{T}-\mathrm{IM}(\mathrm{T})}>\mathrm{L}_{\mathrm{T}-\mathrm{IM}(\mathrm{M})}$

図6，7 より，呈示長さが長くなると，被験者が知覚し た長さも長くなる傾向が見られる. しかし，知覚した長さ が図中の 45 度直線より下に位置することから, 呈示した 実際の長さより短く知覚される傾向が見られた.

$$
\Delta L^{\prime}=L_{T-I M(I)}^{\prime}-L_{T-I M(M)}^{\prime}
$$

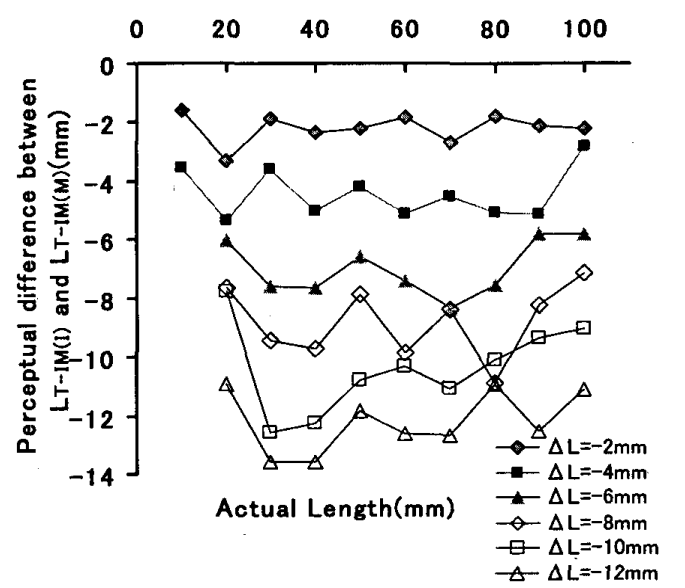

(a) Two lengths perception's difference for condition $\mathrm{L}_{\mathrm{T}-\mathrm{M}(1)}<\mathrm{L}_{\mathrm{T}-\mathrm{M}(\mathrm{M})}$ 


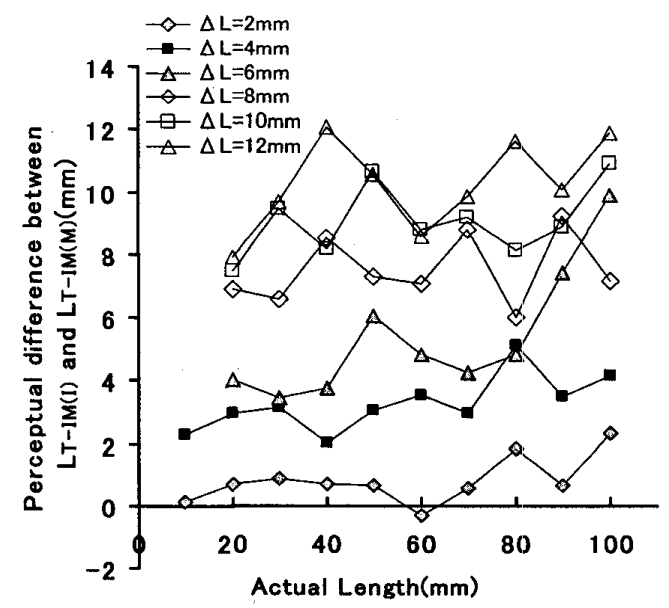

(b)Two lengths perception's difference for condition $\mathrm{L}_{\mathrm{T}-\mathrm{IM}(\mathrm{I})}>\mathrm{L}_{\mathrm{T}-\mathrm{IM}(\mathrm{M})}$

Fig.8 Perception difference of two lengths with three fingers

知覚された二種類の長さの差について検討するた め, それらの差を式(3)のように定義する.ここで, $L^{\prime}$ T-M(M) は被験者が知覚した親指一人差し指間の長さであ る. 三本指に二種類の長さを呈示したとき，知覚した 両者の差 $\Delta L^{\prime}$ を図 8 に示す. 横軸は実際に呈示した 長さを表し，縦軸は被験者が知覚した二種類の長さの 差 $\Delta \mathrm{L}^{\prime}$ を表す. 図 9 に呈示した二種類の長さの差と 知覚された長さの差の関係（平均值と分散）を示す. この図より，呈示した二種類の長さの差 $\Delta \mathrm{L}$ が大きく なると（ $\Delta \mathrm{L}=6 \mathrm{~mm}$ 場合を除く），知覚されている長 さの差 $\Delta \mathrm{L}^{\prime}$ のばらつきが大きくなることが分かる.

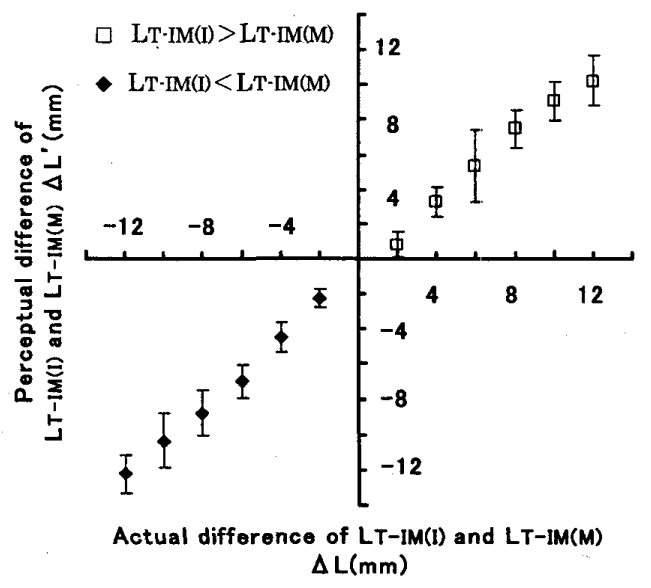

Fig.9 Average difference of two lengths perception with three fingers

\section{4. 考察}

$4 \cdot 1$ 二本指による長さ知党

実験 1 の結果（図

3）より，10 100 $\mathrm{mm}$ の呈示長さ範囲において，呈示さ
れた長さより短く知覚される傾向がある. そして，両 者の差が最大になるのは用いる指に関係なく呈示長さ が 50 80mm のときであり，それ以上の長さを呈示し た場合は両者の差は小さくなっていく.これらのこと から, 呈示長さに対する指の知覚精度が一定でないこ とが考えられる.

また，図 5 (図中の菱形印(•)）に示すように，呈示 長さが変化しても把持力はほぼ一定の值を示している. 特に, 長さ知覚誤差の大きい $50-80 \mathrm{~mm}$ の範囲におい ても把持力の顕著な変化は見られない. 以上のことか ら，文献(10)で報告されているように，把持力は二本指 による長さ知覚に影響を与えないことが確認できた.

$4 \cdot 2$ 三本指による一種類の長さ知覚 图 4 に示 すように，三本指で一種類の長さを知覚する場合，全 体として二本指の場合と同じく, 呈示された長さより 短く知覚される傾向がある. 呈示長さが $50 \mathrm{~mm}$ を超え ると，三本指の方が二本指より知覚誤差が小さくなっ ている. そこで, 呈示長さの範囲を分割して, 多重比 較を行った. その結果, 10 - $55 \mathrm{~mm}$ の長さ範囲では, 二 本指と三本指の知覚結果の間に有意な差が見られなか った. しかし，60 70 $\mathrm{mm}$ の長さ範囲では二本指（親指 一人差し指）と三本指の知覚結果の間に有意な差が見 られた $(\mathrm{p}<0.05)$. また, $80 \sim 100 \mathrm{~mm}$ の長さ範囲では二本 指（親指一中指）と三本指の知覚結果の間にも有意な 差が見られた $(\mathrm{p}<0.05)$. 以上のことから，60 100 $\mathrm{mm} の$ 長さ範囲において三本指のほうが二本指より長さに関 する知覚精度が高いといえる. 三本指と二本指の長さ を知覚する際の指の動きを比較すると, 中指の付け根 の関節（中手指節間関節）の動きが付加され，三本指 の場合は二本指の場合より広い面積の運動野で伝達さ れた情報が処理されるため，知覚された結果の精度が 高くなると考えられる.

また，図 4 から，指の本数に関係なく呈示長さが 50-80mm のときに長さ知覚精度が最も悪くなってい ることが分かる. これらの長さは，把持できる最大長 さ（親指一人差し指間であれば $120 \mathrm{~mm}$ 程度, 親指一 中指間であれば $150 \mathrm{~mm}$ 程度）の半分となっている. 指の付け根にある関節（中手指節間関節）が屈曲・伸 展する場合, 指の可動範囲は最小值・最大值となり, この関節に関係する筋肉の動きは大きく，脳に伝達さ れる情報量は多くなる. 一方, 指の稼動範囲が $50 \%$ 程 度の場合は，指は自然の状態に近く，脳に伝達される 情報量は少なくなる．そのため，指の可動範囲の $50 \%$ 程度の長さに対して最も長さ知覚精度が悪くなると考 えられる。 


\section{5. 結 言}

把持力に関して，文献(10)では，50,53, 56, 59, 62mm の長さ刺激を $250 \mathrm{~g}, 500 \mathrm{~g}, 750 \mathrm{~g}$ といった異なる把持力 を用いて知覚する実験を行っている. その結果，異な る把持力を用いて長さを知覚しても, 知覚された長さ 間に有意な差がないことが分かっている. 図 5 に示す ように，二本指と三本指の把持力は呈示長さに関係な くほぼ一定であり，上述したようにこのときの長さ知 覚精度は一定でない，また，両者の平均把持力を分散 分析した結果, 二本指と三本指の把持力には有意な差 が見られなかった.これらのことから，文献 ${ }^{(10)}$ と同様 に，三本指の場合でも把持力と長さ知覚精度の間には 有意な関係がないと考えられる.

\section{4・3 三本指による二種類の長さ知覚 三本指を} 用いた二種類の長さ知覚実験では，親指一人差し指間に呈 示した長さが親指一中指閒に呈示した長さより短い場合 $\left(\mathrm{L}_{T-M M}<\mathrm{L}_{T-M}(M)\right.$ 之逆に長い場合 $\left(\mathrm{L}_{\mathrm{T}-\mathrm{MM}(0)}>\mathrm{L}_{\mathrm{T} T M M M}\right)$ の条件で測定 を行った、いずれの条件においても，呈示長さより短く知 覚される傾向があった.この傾向は一本指や三本指を用い た一種類の長さ知覚実験こおいても確認されているため, 指の本数や呈示長さの種類には無関係な傾向であると考 えられる。

一種類の長さ知覚 (実験 1,2 図 3) と二種類の長さ知 覚 (図 6,7) について比較する.いずれの場合も $10-50 \mathrm{~mm}$ の呈示長さ範囲にお注る知覚誤差恃, 呈示長さが長くなる につれて大きくなっている. 一方, 60 100 $\mathrm{mm}$ の呈示長さ 範囲では，一種類の長さを呈示した場合の知覚誤差は呈示 長さが長くなるにつれて減少している. 図3において, 呈 示した実際長さが $100 \mathrm{~mm}$ のときにはほぼ $100 \mathrm{~mm}$ と知覚 されており，知覚誤差はほとんどないしかし，二種類の 長さを呈示した場合の知覚誤差はほとんど変化しなかっ た. 図 6,7 において，実際長さが 70〜100 $\mathrm{mm}$ のとき知覚 誤差はほぼ $20 \mathrm{~mm}$ 程度である.このことから, 知覚誤差は, 知覚すべき長さの種類と情報を収集する指の数に左右さ れることが推測できる.

呈示された二種類の長さの差に関する知覚（図9参照) では，呈示した二種類の長さの差 $\Delta \mathrm{L} か ゙ 6 \mathrm{~mm}$ を境として ほほ同じ傾向を示している. しかし，それらの分散は異な る. 例えば， $\Delta \mathrm{L}=6$ のとき $\mathrm{L}_{\mathrm{T}-\mathrm{M}(\mathrm{M})}<\mathrm{L}_{\mathrm{T} M(M)}$ の分散は 0.93 であ り， $\mathrm{L}_{\mathrm{T} M(M)} \mathrm{L}_{\mathrm{TIMM})}$ の分散は 2.10 である.このように,

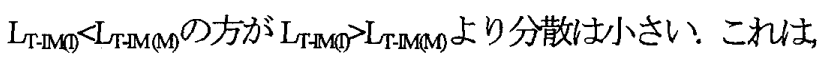
親指一人差し指間より親指一中指間の長さが手の骨格構 造上長いことから， L LTMO $L_{T-M M}$ の条件で長さを知覚して きた経験が多いため，分散が小さくなったと考えられる.
本研究では，二本と三本指の把持動作による長さ知覚の 差異を検討するため, 任意の長さの呈示ができる実験装置 を製作した. 製作した実験装置を用いて親指と人差し指お よひ親指と中指による一種類の長さ知覚実験 (実験 1)， 三本指による一種類の長さ知覚実験 (実験2），三本指に よる二種類の長さ知覚実験（実験 3）を実施した.

実験 1 の結果より, 親指一人差し指間と親指一中指間の 長さ知覚精度には差異がないことが分かかた. しかし実験 3 の結果より，これらの指間に同時に一種類の長さを呈示 した場合は， $\mathrm{L}_{T-M M}<L_{T-M M}$ の方が知覚誤差の分散が手の骨 格構造上小さくなることが分からた. 三本指 (親指と人差 し指・中指) を用いて一種類の長さ知覚をした場合 (䒠験 2），二本の指（実験 1）と比較すると 60-100 $\mathrm{mm}$ の長さ 範囲において, 三本指のほうが二本指より知覚精度が高い ことが分かった.さらに，三本指を用いた場合でも把持力 は長さ知覚に影響を与えないことが明らがなった。この ことから, 長さ知覚の精度は，呈示される長さの種類と情 報を収集する指の数に左右されることが推則できる.

\section{文 献}

(1) Burke D, Gandevia SC, and Macefield G, Responses to passive movement of receptors in joint, skin and muscle of the human hand. The Journal of Physiology 402: 347-361,1988.

(2) K. T. John1, A. W. Goodwin and I. Darian-Smith, Tactile discrimination of thickness. Experimental Brain Research, $62-68,1989$

(3) GAYDOS, H F, Sensitivity in the judgement of size by fingerspan, American Journal of Psychology, 71, 557-562.1958.

(4) DIETZE, A G. Kinaesthetic discrimination: the difference limen for finger span, joumal of Psychology. 51, 165-168. 1961.

(5) LU Shengfu, SAKAI Yoshiro, WU Jing-long, YAMAMOTO Masayuki, Measurement and Analysis of the Object Length Perceptive Characteristics with Visual and Tactile Information for Proposal of Three-Dimension Tactile Shape Display, Transactions of the Jopan Society of Mechanical Engineers. C, Vol.70, No.697 pp. 2699-2706(2004)

(6) Johnson KO and Hsiao SS, Neural mechanisms of tactual form and texture perception, Anmual Review of Neuroscience 15: 227-250, 1992.

(7) Westling G and Johansson RS, Responses in glabrous skin mechanoreceptors during precision grip in humans. Experimental Brain Research, 128-140,1987

(8) Loomis, J.M. and Lederman, S.J. CHAPTER 31 Tactual perception. Handbook of Perception and Human Performance, vol 2, pp. 1-41. New York: Wiley. 1986

(9) Gepshtein S and Banks MS, Viewing geometry determines how vision and haptics combine in size perception, Current Biology 13: 483-488, 2003.

(10) L. J. Berryman, J. M Yau and S. S. Hsiao, Representation of Object Size in the Somatosensory System, Joumal of Neurophysiology 96:27-39,2006. 